\title{
What Cultural Objects Say About Nuclear Accidents and Their Way of Depicting a Controversial Industry
}

\author{
Aurélien Portelli
}

\begin{abstract}
Nuclear accidents have prompted the creation of numerous cultural objects such as novels, films, cartoons, or posters. Here we show what these objects can teach us about the social representations of nuclear power. The object is both a product and a representation. It can influence attitudes and partially contributes to the cognitive context of controversy about atomic power. Consequently, it leads to diverse practices defined by the interests and goals of the groups that own it. French documentaries on Fukushima Daiichi constitute a coherent corpus that makes it possible to identify both ruptures and continuity in the story that is told. These films borrow from the symbols, myths, and analogies provoked by Chernobyl to evoke Fukushima. They also show that the accident ends the myth of 'Soviet neglect' and creates a form of social resilience that has changed the way the Japanese population is seen in France.
\end{abstract}

Keywords Cultural object - Representation - Socio-technical controversy • Nuclear disaster - Citizen mobilization

\section{Introduction}

A monumental tower occupies the center of the picture. To the left, the viewer can discern a city; to the right, a body of water and a dock with ships. In the foreground, stonemasons pay homage to King Nimrod; behind them, there is a denselypopulated city. A multitude of tiny workers are working on the tower, which is still under construction. The people decided to build a city, "with a tower that reaches to the heavens" [1]. But God intervenes, He garbles the words of the workers, work stops and the city is named Babel. In this picture, painted by Bruegel the Elder in 1563 [2], the tower is "the spiral of knowledge, the relentless swarm and the image

\footnotetext{
A. Portelli $(\square)$

Centre for Research on Risks and Crises (CRC),

MINES ParisTech/PSL University Research, Paris, France

e-mail: aurelien.portelli@mines-paristech.fr

(C) The Author(s) 2017

J. Ahn et al. (eds.), Resilience: A New Paradigm of Nuclear Safety,

DOI 10.1007/978-3-319-58768-4_11
} 
of pride" [3]. In 1975, the graphic designer Peter Brauchli reproduced this painting as a poster, replacing the top of the building with the cooling tower of a nuclear reactor. ${ }^{1}$ The poster was shown in 1979 in the context of an anti-nuclear campaign in Switzerland [4]. It symbolizes the technological excesses and the catastrophes that nuclear power could lead to.

The image that this picture paints reflects societal fears that were materialized by the 1986 Chernobyl accident. It happened again, 25 years later, with the Fukushima Daiichi accident. Commentators evoked a tragedy, for example in the article entitled "The Japanese Nuclear Industry, or a Punishment for Hubris" [5]. The media noted that there would be no end to the Japanese disaster, which became a very controversial element in debate about the industry. Some representations, which had been mothballed when the dust of the 'battle of Chernobyl' had settled, were reactivated in the collective consciousness and were reflected in novels, films and comic books. In turn, this material, collectively termed 'cultural objects' [6] interacted with existing images and produced new ones.

This chapter shows what cultural objects can teach us about the representation of accidents and the nuclear industry. The first section defines the terms 'representation', 'socio-technical controversy' and 'cultural object'. The second describes the characteristics of the object, as both a representational product and agent. Finally, the third section examines French documentaries about Fukushima, and discusses the consequences of the nuclear accident on representations.

\section{Social Representation, Controversy, and Cultural Objects}

The literature on social representations reveals analytical models that are based on several types of data. Representations may relate to a controversial technology, such as nuclear energy. The controversy arises from identities and practices that impact the production and reception of cultural objects. Works related to nuclear accidents therefore have several things in common: they dramatize it; they often confuse civil and military applications; and they therefore have a more-or-less close relationship with reality.

\subsection{Social Representation}

The analysis of representations in the social sciences has led to many definitions. Nonetheless, a certain degree of consensus emerges, such as Gaffié, "A social

\footnotetext{
${ }^{1}$ Bruegel executed at least two versions of The Tower of Babel. The first (1563) was shown in Vienna, the second (1568) in Rotterdam. It is the Viennese version that was used by Brauchli.
} 
representation takes the form of a set of knowledge, beliefs, patterns of understanding and action about a socially-relevant subject. It is a particular form of common-sense knowledge that defines reality for the society that developed it with the aim of action and communication" [7]. It manifests both as the sum of content and as a process that can modify thoughts and actions.

Moscovici, the pioneer of the theory of social representations, identifies two major processes in their development: objectification and anchoring [8]. The first designates the origin of the formalization of knowledge about an object. It embodies the meaning of things and facilitates discussion [9]. Objectification is divided into three phases: selection (sorting and taking ownership of information depending on the cultural context), schematizing the selected elements (construction of a coherent picture leading to the simplification of the represented object), and naturalization (the constructed image becomes, for the actor, an autonomous and objective entity). Anchoring extends objectification with the ultimate aim of integrating the novelty into the social space [10]. This process corresponds to the instrumentalization of the object, so that actors can actually use it. Anchoring the novelty can then lead to a change in thinking. Objectification and anchoring therefore show how society transforms knowledge into representations, and how this in turn transforms society [9].

Various analytical models subsequently appeared, such as genetics, dynamic or structural perspectives [11]. The latter sees social representation as a socio-cognitive system consisting of a central core and a peripheral system that complement each other [12]. The central core is the fundamental and non-negotiable element of the representation. It functions as both a generator and organizer. The first determines the meaning of the components of the representation; the second defines the nature of the links that connect these elements. The core is characterized by its stability and its ability to resist contextual developments or the introduction of new practices. The peripheral system is more permeable to change. It is subordinate to the core and provides the connection between the central elements and the social reality of the object. The representation of the peripheral system can be adapted to the context; this ensures the integrity of the central core, which remains protected. Although the structural approach has evolved since its initial definition [13], it remains relevant for understanding social representations.

Their study is based on several types of data. Research has focused on various discursive elements, in the form of (undirected or semi-directed) interviews or questionnaires. A second source is conversations and other forms of verbal interaction in a group or public place. The third is a textual and iconic corpus (archives, novels, newspaper articles, cartoons, paintings, comic books, photographs, and films), while word association tests form a fourth set [10]. All of these content types highlight statements, analogies, and meaning from which social representations can be developed. They can also prove to be a major societal issue, as the controversy over nuclear technology demonstrates. 


\subsection{Socio-Technical Controversy}

Socio-technical controversy refers to a public debate in which opposing arguments are used to interpret an object or a particular technical system. This debate is not limited to a community of specialists - unlike, for example, scientific controversy [14] - and involves heterogeneous actors who introduce technical and non-technical (economic, social, health, moral, etc.) arguments. ${ }^{2}$ The development of nuclear energy in France was uncontroversial until the late 1960s, when the anti-nuclear movement emerged. The initial phase (1970-1974) established the founding ideas [16]. Environmental activists, who emerged from the events of May 1968, accused the nuclear sector of shifting society towards a technical and authoritarian model. They proposed the establishment of an alternative, decentralized libertarian and autonomous society and carried out a diverse range of actions: demonstrations, boycotts, site occupations, petitions, etc.

The movement expanded to a national level in its second phase. This began in 1974 with the announcement of the Messmer Plan. ${ }^{3}$ Protestors rejected this massive nuclearization of France. The nuclear program, in addition to threatening the environment and human health, was accused of strengthening capitalism, the technocracy and state authoritarianism. The attitudes of militants hardened: there were bomb attacks, clashes with police (for example, Creys-Malville in 1977), and acts of sabotage. Faced with mounting opposition, pro-nuclear supporters took action and the state-owned power company EDF launched an information campaign to reassure the public, who remained largely in favor of nuclear energy. The fact that the accident at Three Mile Island (in March 1979) had little effect on public opinion confirmed the relative acceptance of nuclear power in France, and the suffocation of the protest movement.

The Chernobyl accident, however, marked a break and initiated a period of controversy. Although there were very few antinuclear demonstrations in France, the reassurances issued by the authorities, coupled with a lack of information and preventive measures, led to a change in how things were done. Research into alternative solutions expanded and there was a massive increase in the number of alerts. In return, industry actors changed their message and attempted to make nuclear power less opaque and more democratic.

New groups appeared in the 1990s (although not at the same level as in the 1970s), while the debate was revived by the Fukushima accident in 2011. The media questioned the safety of French installations, waste management, the profitability of the sector, the working conditions of subcontractors, and the feasibility

\footnotetext{
${ }^{2}$ For some authors, controversy is different to institutional crisis. The first involves an audience made up solely of peers, while the second involves a wider, non-specialized public. However, in most cases, controversies "go beyond the circle of peers and engage social forces and individuals who are located beyond the institutional scope in which they arose" [15].

${ }^{3}$ Prime Minister Pierre Messmer announced, in March 1974, the expansion of the nuclear power program, together with plans to build 13 nuclear plants in 2 years.
} 
of decommissioning. The reaction of the European Union was ambivalent: Germany brought forward the date of the closure of its plants, while France refused to abandon nuclear power. Several factors explain the failure to radically reexamine the French nuclear sector. Politicians simply relegated the Japanese accident to an exceptional event: "Twenty-five years after the Chernobyl accident, the exception has again served as the main element of arguments that aim to provide reassurance: the Japanese geographic exception has now replaced the Soviet technological exception (victims of their lack of technical expertise)" [16]. Experts issued reassurances that they would take into account feedback from the Fukushima accident to "imagine the unimaginable", and strengthen plant safety. Political and industrial actors, profiting from the Chernobyl experience, promoted transparency. ${ }^{4}$ Politicians managed to make nuclear energy acceptable, and effectively prevented any further escalation of the dispute.

The French nuclear energy controversy therefore has several particular characteristics. It is both technological ('the industrial war' between supporters of the French and American technology in the late 1960s) and post-technological (site selection, rejection of large-scale nuclearization). ${ }^{5}$ The controversy over the industry, and more generally the issue of radioactivity [19], has developed slowly, with periods where it has received little attention, followed by periods of intensification or renewal. This periodicity implies changes in the composition of social groups that are involved, and a change in their strategic action plan. Going beyond issues of energy policy, accident risk, or environmental and health impacts, French controversy is intrinsically linked to power struggles in society, underlined by the concept of technopolitics. ${ }^{6}$ It also questions other ideas, such as the relationship between Man and Nature. Controversy emerges from the construction of identities and strongly-held collective practices (the pride of nuclear energy pioneers, the collective memory of militants at Plogoff or Creys-Malville), which plays a part in the production and reception of cultural objects.

\footnotetext{
${ }^{4}$ The contribution of the anti-nuclear movement to the history of the industry illustrates the thesis of Lascoume on the social production of controversy [17]: "Criticism has helped to modernize nuclear institutions, forcing them to improve their communication strategies and crisis management systems, requiring them to improve their communication with the public, bypassing the dominant idea in 1986 that all means - first and foremost extreme secrecy-were useful in order to preserve the future of nuclear energy" [16].

${ }^{5}$ This distinction mirrors that of Callon in his article about the sociology of technological controversies [18], where he suggests that controversies emerge during, but not after technological invention.

${ }^{6}$ This concept corresponds to strategic practices that consist of designing or using technology to implement policy objectives [20]. Technopolitical regimes designate groups of individuals, engineering and industrial practices, technical objects, political programs and institutional ideologies. These elements are connected to each other and interact to govern the development of technology and in turn, enable technopolitics to develop.
} 


\subsection{Cultural Objects}

Taking actual objects as our starting point (rather than the social groups who appropriate them) offers a new perspective on representations. In this case, objects are not considered as independent and decontextualized entities, but are observed through the prism of the history of aesthetic representations, which "makes it possible to think about knowledge, ideologies and the techniques that are implemented-which should certainly avoid a linear story form-the relationships between the object of the representation and its production or reception" [21].

The cultural object is a reference to "all concrete objects (books, writings, paintings, photographs, films, architecture, sculpture, etc.) resulting from a formal production and intended to produce in those who receive it a symbolic 'effect' (aesthetic contemplation, subscription to its values, producing a belief, etc.)" [6]. This type of object "is part of a civilizational and historical context and participates in the definition of the worldview of which it is a part" [22]. It is disseminated in communities of varying homogeneity and scope. Its influence on social reality is therefore difficult to assess and the researcher must collect external data. They can then compare the cultural object with other sources to determine its function in the public space and its contextual significance, or examine its reception by critics. Comparisons, which depend on the availability of sources, should not however be carried out at the expense of the internal analysis of the object. In practice, the object is involved in the formation of social processes, but remains a product whose constituent elements must be carefully studied, as it is the starting point for research.

Cultural objects relating to nuclear accidents are very diverse in terms of both form and content. However, they all approach the subject from a dramatized angle, as is shown in the confusion between a nuclear reactor and a nuclear weapon. Objects draw upon radioactive imagery marked by Hiroshima and Nagasaki, the anxiety generated during the Cold War, and the proliferation of weapons of mass destruction. The image of the mushroom cloud is particularly evoked as a representation of the explosion of a nuclear reactor. As an example, the city of Springfield is destroyed in an episode of The Simpsons [23] as a result of the explosion of a nuclear plant, in the same way that Hiroshima was razed to the ground by Little Boy. The similarity with reality highlights the discursive potential of a cultural object, which maintains a dual relationship with social representations. ${ }^{7}$

\footnotetext{
${ }^{7}$ The position of the author, as a representational actor, must be taken into account in this process. Their role is easily identifiable when it concerns a novel or a comic book. The notion of authorship becomes more ambiguous with respect to a film. The director cannot by themselves embody the author, and is seen more as a "virtual home", a "speaker", or the "subject of filmic discourse" [24]. The discourse is therefore not always individualized and can result from a collective effort.
} 


\section{The Cultural Object in Representations of the Nuclear Sector}

First and foremost, the cultural object can be seen as a product of social representations. The Chernobyl accident caused a representational crisis. What resources and symbolic systems were available to represent the radioactive 'evil'? The nuclear crisis therefore led cultural actors to reflect on how to represent an invisible evil $^{, 8}$ and its impact on perceptions of reality. But the cultural object is more than a product of social reality. It is also an agent involved in the creation of representations and in the structuring of socio-technical controversies.

\subsection{The Object as a Product}

One approach suggests a cultural history of nuclear accidents, consisting of "all forms of collective representations, how societies see and represent what is external to them, symbolically through values, spiritually through belief systems, intellectually through the construction of ideas, and pragmatically through image- or textbased techniques (discursive practices) or other means (non-discursive practices)" [4]. The researcher must therefore explain how the nuclear accident is a break with (or a continuation of) representations of risk perception and its relationship with social reality.

The nuclear accident is represented as a catastrophe, which can be defined as an "event causing a disaster of major magnitude, whose social and symbolic consequences are on a historical scale" [26]. The unending consequences of Chernobyl marked a radical change: they created an area that was out of bounds to the world, manifested by the abandonment of vast areas where the invisible threat of radiation lurked [27]. Beck notes, in the preface to his book Risk Society [28] that mankind has always responded to suffering, misery and violence by resorting to the 'Other'. Chernobyl put an end to this ability to put events at a distance. Since the Soviet accident, it has not longer been possible to ignore the dangers of the nuclear age. From that point, fear became the product of the most advanced levels of progress in the modern world.

Using an apocalyptic scenario, cultural objects represent the anguish that the Soviet accident triggered. The novel Silence, we're irradiating (Silence, on irradie) [29] suggests that even the normal operation of a nuclear installation foreshadows disaster. In this novel, workers suffer from all kinds of illnesses: headaches, loss of teeth, dark spots on the skin. Children suffer from physical defects, mental

\footnotetext{
${ }^{8}$ The term radioactive 'evil' comes from the work of Dupuy on "the empowerment of evil with respect to the intentions of those who commit it" [25]. In the case of Hiroshima, evil comes from the intention to commit evil, while in the case of Fukushima, evil comes from the intention on the part of industrial actors to do good.
} 
handicap, and lose their hair. It is rumored that the lake close to the plant is populated with monster fish. The novel paints a picture of degeneration that reflects concerns about the sector. The description of the explosion of the plant reflects both the destruction of Hiroshima and the Chernobyl accident, "Over more than a kilometer in circumference, an irradiated graphite storm hit, corroding vegetable, mineral, and animal alike. The building that housed the families of engineers and workers had been pulverized. It left the distressing spectacle of a crater containing rubble magma, covered with a layer of tilled soil" [29]. Sven, a teenager, falls into a ditch and survives. He returns to his village but finds it has been replaced by a post-apocalyptic scene: "It was a ghost town that he saw before him" [29].

This image of the apocalypse demonstrates the violence of the technique, which some authors interpret as a form of transcendence. Viewers of the sarcophagus of Chernobyl are seized by a "holy terror" [30]. This sacredness is represented as a nightmarish vision in Mount Fuji in Red [31]. This short film begins with an outline of Mount Fuji, which has begun to erupt. Below, people flee in panic. Balls of flames shooting into a scarlet sky, rise behind the volcano. Nuclear power plants explode in succession, triggering huge fireballs. The awakening of Mount Fuji, the sacred mountain of the archipelago, causes a chain reaction that is a punishment for the hubris of mankind. The sequence, linking the cataclysm to spirituality, is a representation of divine punishment that is both specific (the volcano is revered by the Japanese) and universal (the myth of the end of the world). The use of religious symbolism and variations on the myth of the Apocalypse reflect an extreme situation in the sense that Eliade understands as "what mankind discovers by understanding its place in the Universe" [32]. The representation highlights the appetite for technology in modern societies and the powerlessness of mankind in the face of the forces it has unleashed.

\subsection{A Representational Crisis}

The Chernobyl accident can be compared to the Holocaust or Hiroshima in the sense that it marked the start of a new world, "The world of Chernobyl, the product of technoscience, appears to have made all cultural resources mobilized in such situations obsolete: it becomes impossible to use such a system of representation, analogy or experience to understand this world that has become so alien to mankind, denatured and unrecognizable, while at the same time, familiar" [26]. The use of color quickly proved decisive in circumventing the problem of the 'impossible representation'. In Mount Fuji in Red, the explosion of plants produces red and purple clouds of radioactive particles. A survivor explains this strange phenomenon, "Human stupidity is boundless. Radioactivity is invisible, while technology has been developed that colors it when it spreads in the air" [31]. In this case, the discourse links the nuclear industry to an industry that is as dangerous as it is counterproductive. The use of color is seen again in the film The Land of Hope [33]. At the same time as an accident occurs in the Nagashima plant (a contraction 
of Nagasaki, Hiroshima and Fukushima), a resident goes to a clinic and learns that she is pregnant. She heads for the exit and sees behind the glass door red smoke that obscures the street. A reverse shot shows a close-up of the character. The color red, symbol of radioactive hell, is reflected in her eyes. A blinking eyelid breaks the illusion, but the young woman is now possessed-by the fear of contamination.

The sensory impact of the accident is approached differently in A Springtime at Chernobyl (Un printemps à Tchernobyl) [34]. In this comic book, Lepage recounts the story of his stay in the prohibited area in 2008. The graphics use black and white and sepia tones. A two-page spread presents a twilight landscape, where electricity pylons fill the foreground, symbol of the 'electricity fairy' and the modernity of which it is the corollary. The antinomic and threatening shadow of the plant fills the background, represented as a haunted mansion. The use of half-light and violent contrasts add to the gloomy gravity of the scene. Drawings of the area, with its twisted trees and buildings in ruins, follow one after the other. An overview of Pripiat shows a petrified town that has been overtaken by vegetation, like cites abandoned by the Maya. The town, designed to be a showcase of Soviet modernism, "takes us back to the light of an extinct empire [...] like a dead star" [34]. A sudden patch of green forest marks a break with the gloom of previous images. Lepage changes the iconic registry and shows a world without humans, where a transfigured nature has resumed its rightful place. The artist describes his discomfort: "It's calm all around me. These places suggest pleasure... But I'm at Chernobyl! How can I reflect this improbable situation? Only through scientific artifice. The number of micro Sieverts shown under each drawing. What's in front of me, what I'm drawing is not the truth! I don't see the disaster but an explosion of magnificent colors. (...) How can I draw the invisible?" [34]. This inner monologue expresses the paradox posed by the area, which is as horrible as it is radiant. The indecent beauty of nature, created by nature itself exerts a fascination reminiscent of the romantic landscapes of the nineteenth century. However, the voluptuous forms and colors suggest a betrayal of reality. This is a defining characteristic of the representation of radioactive areas, whose construction depends on the contradictory phenomenological elements that compose it.

\subsection{The Object as Agent}

The cultural object, in addition to being a product, is also a representational agent. The process of integrating the object into social reality involves the selection and crystallization of certain elements of the representation of the nuclear accident. This can influence thinking and contribute to the controversy over the industry. The object is associated with diverse practices, defined by the interests and objectives of the groups that own it. Crystallization may therefore require the instrumental use of the cultural object, especially when groups that engage in the controversy are ideologically motivated. Its use therefore becomes strategic, as it allows group 
members to mobilize, act and to rally other individuals who are less concerned about the cause.

The anti-nuclear movement contains many examples that illustrate this function of the object. The online shop belonging to the French Nuclear Exit Network (Réseau Sortir du Nucléaire, RSN) ${ }^{9}$ is full of merchandise: the Nuclear Exit journal, books, DVDs, games, leaflets, posters, stickers, flags, T-shirts, banners, etc. A first category of objects concerns products that are sold commercially, and in the Network's webshop, such as the novel Silence, we're irradiating. The second category consists of articles specially designed by the RSN, such as the DVD entitled Short Films (Films courts). This DVD contains twenty short films screened at a festival organized by the Network on April 26, 2008, for the 22nd commemoration of Chernobyl. The liner note points out that "cinema is an important tool for raising awareness, it is often more widely accessible than the written word". The group invites its militant members to organize public screenings of the DVD, in the context of an information campaign about nuclear power. A further example is the poster Gaul under nuclear occupation (La Gaule sous occupation nucléaire) [35], which uses humor to denounce the sector. The poster is a parody of the map found in the comic book Asterix, ${ }^{10}$ which shows the occupation of Gaul by the Romans following Caesar's conquest. In this case, it is nuclear power plants that occupy France, 70 years after the bombing of Hiroshima. Facing the nucleocrats entrenched in their garrisons stand the indomitable Gauls, who lead the resistance. The illustration Latinizes the names of nuclear sites, which become Marculus or Golfechus. The European Pressurized Reactor (EPR) at Flamanville becomes the Extra Problemus Reactus and the plant at Fessenheim is renamed Fissurnhum. Corsica is renamed Postum Tchernobylum in reference to the (controversial) radiological consequences of the Soviet accident. The eagles and standards of Rome are replaced by the names of industrial actors in the sector. The poster is a prophecy of a nuclear disaster in France. A place called Tsunamus appears on the Atlantic coast, while the Chinon plant is renamed Fukushinum. The image therefore makes reference to an object that is very representative of French popular culture to synthesize the main arguments of the public debate and denounce the country's widespread nuclearization. Cultural objects sold on the RSN website allow the Network to disseminate its ideas, encourage the user to take direct action, and strengthen its militant identity, by creating content that can be easily used by individuals. Objects therefore help to build a shared culture and create a permanent construction for the collective.

\footnotetext{
${ }^{9}$ The aim of the Network, founded in 1997, is to secure the exit of France from nuclear energy and promote alternative energies. It currently brings together 931 associations, while 60,290 individuals have signed its charter. Its actions take many forms: information campaigns, raising awareness with elected officials or unions, petitions, lawsuits, etc.

${ }^{10}$ Asterix is a series of French comic books, created in 1959 by Goscinny and Uderzo. It narrates the adventures of a group of French Gauls who resist the Roman invasion thanks to the power of a magic potion.
} 


\subsection{The Value of the Cultural Object}

For the researcher, the value of the cultural object lies in its symbolic specificity. By highlighting what is 'built', the object creates a synergy between cultural references. Its analysis makes it possible to access social representations in ways that do not involve interviews or surveys. The object has a dual role, notably in terms of structuring day-to-day conversation - objects feed discursive dynamics and stimulate the production of new representations.

Regarding the nuclear industry, the production and circulation of content is a battleground that the groups involved in the controversy must conquer. While the use of military terminology may seem excessive, it is not possible to orient decisions and actions without first changing the representations that are associated with them. Therefore, how the sector is represented can, depending on the societal context, become a fundamental issue in drawing up energy policy.

Content analysis, however, should not be at the expense of a more aesthetic approach to representations. The iconic and narrative dimension of the object (through the formalization of content), is a major contributor to the constitution of knowledge and understanding the world. Furthermore, the study of forms (in the broadest sense), is useful in identifying which of the elements created by an event lead to rupture or continuity in the representation of reality. In this respect, French documentaries about Fukushima constitute a coherent corpus that can be used to analyze the impact of the disaster on representations.

\section{The Representation of Fukushima in French Documentaries}

French documentaries use the Japanese accident to illustrate the globalization of risk and the repetition of history. The 'never-ending' accident is dramatized: the actors involved in the management of the crisis are incompetent, workers involved in decontamination are sacrificed on the altar of atomic power, and populations are abandoned to their fate. Faced with disaster, civil society reorganizes itself and the various initiatives taken by citizens lead to some sort of social resilience.

\subsection{The Space-Time of the Disaster}

The documentary Nuclear Disasters: Secret Stories (Catastrophes nucléaires: histoires secretes) [36] begins with a close-up of the Fukushima site, filmed on Saturday, March 12, 2011. Reactor 1 explodes in the next shot. Extracts from televised news programs emphasize the scale of the disaster, while the damaged reactor appears once again. Images of the explosion are shown around the world, reminiscent of those of the planes that crashed, 10 years earlier, into the World 
Trade Center. This repetition reflects the extent of the trauma, which is permanently engraved in the collective memory.

These representations superimpose the natural and technological dimensions of the disaster. In the documentary The World after Fukushima [37], a lateral tracking shot reveals a landscape devastated by the earthquake and tsunami. Shots of abandoned buildings and heaps of debris follow. The commentary indicates that the accident was caused by the earthquake and tsunami of March 11, but that the real causes lie in the weaknesses of a system "whose arrogance was matched by its blindness" [37]. These words modify the images by associating the damage caused by the tsunami with the consequences of the accident. It is the infinite extension of a war zone, says the narrator. In the documentary Fukushima, Particles and Mankind (Fukushima, des particules et des hommes) [38], color drawings show familiar places: a neighborhood, houses, cultivated fields. A whitish vapor, full of radioactive particles, spreads over the scene. This represents the 'invisible evil'. It emphasizes the deviousness of the threat, and calls into question the reliability of our senses and reality.

The Fukushima accident is open-ended and illustrates the theory of the risk society [28]. The documentary Fukushima, a step towards global contamination (Fukushima, vers une contamination planétaire) [39] reveals that tuna caught off San Diego (United States) were contaminated with cesium waste from the damaged plant. The same observation is made in frozen fish sold in Switzerland. The globalization of risks is such that all consumers are potential victims of Fukushima. Furthermore, the disaster is shown to be a repeat of history. As the lateral tracking shot in The World after Fukushima fades out, it is followed by a new shot. This sequence consists of archive black and white images, recorded on August 6, 1945 at Hiroshima. The landscape scrolls across the screen and ends with a field of ruins, which appears to be the continuation of the previous shot. Hiroshima and Fukushima are therefore merged into one, single atomic energy catastrophe. ${ }^{11}$ The analogy is highlighted by a vertical panorama from the Genbaku dome, ${ }^{12}$ where the sequence ends. The camera rests on the reflection of the building on the surface of the River Ota, highlighting the parental relationship between the two events. ${ }^{13}$

\footnotetext{
${ }^{11}$ The Fukushima crisis accentuates the media conflation between the civilian and military nuclear sectors, "The nuclear power plant is the twin sister of the atomic bomb: it uses the same, extremely dangerous substances. Its civilian character does not remove that fact that is the twin of nuclear weapons. The nuclear power plant is deadly technology that has been tamed" [40].

${ }^{12}$ This building, built in 1915, is the former Prefectural Industrial Promotion Hall at Hiroshima. It was the only building left standing following the explosion of Little Boy. It has been listed as a UNESCO World Heritage Site since 1996.

${ }^{13}$ The media has advanced many reasons for the development of nuclear power in Japan. According to T. Tanaka, Professor at Hiroshima University, "It is precisely because we were victims of the atomic bomb that the arguments of civilian nuclear supporters appealed to us. For them, the technology that killed our loved ones could not only treat cancer, but also bring us comfort". On the other hand, for the essayist M. Katayama, nuclear power was developed in response to a desire for revenge, "Based on the fact that Japan lost the war because of its scientific backwardness, we concluded that we had to take our revenge by triumphing in exactly that domain" [41].
} 
Fukushima is not only represented as a new Hiroshima, but also as yet another nuclear disaster. The warnings provided by Three Mile Island and Chernobyl were not heeded, and it was therefore no surprise that another accident occurred in Japan. The event is all the more unacceptable as it had been foreseen. In the documentary Japan: Nuclear energy, the sector of silence (Japon: Nucléaire, la filière du silence) [42] the former Prefect of Fukushima presents a series of damning documents. Workers had highlighted, well before the accident, technical problems and safety breaches at the site. "The failings revealed by whistleblowers were never addressed. This is what led to the accident we see today" [42]. The narrator states that these failures and the accumulation of errors did not prevent the operator receiving, in February 2011, authority for Reactor 1 to operate for another 10 years, although the facility was already 40 years old.

The commentary implicitly refers to the debate taking place at the same time in France about the Fessenheim reactor in Alsace. In April 2011, thousands of protesters demanded that this grande dame of French nuclear power be decommissioned, "A month after the earthquake and tsunami in Japan, which caused a serious accident at the nuclear plant of Fukushima, antinuclear protestors focus on the age of the Fessenheim plant, built in 1977, arguing that it is also located in a seismic zone and is subject to the possible flooding of the Rhine" [43]. The documentary, Nuclear Energy: the Human Bomb [44] shows images of anti-nuclear demonstrations. A sign held up by a young boy says "No Fukushima in Alsace". This prophetic message illustrates the idea of "enlightened catastrophism" [45]: the message is that the warning provided by Fukushima should lead to the closure of the Fessenheim plant, if history is not to repeat itself.

\subsection{The Story of an Accident that Has no End}

These images denounce the lack of responsiveness and the incompetence of the actors involved in the crisis. In Nuclear Disasters, connecting car batteries to control panels with alligator clips is not seen as an ingenious solution. It demonstrates a lack of resources and becomes proof of the amateurism of the operator. ${ }^{14}$ Similarly, the documentary discredits Prime Minister Naoto Kan. Government actions are labored and inefficient. For example, a helicopter is sent to spray water on the plant. The Japanese population saw these images projected on a giant screen and "noted with dismay the inability of their country, the third largest economy in the world, to cool the Fukushima reactors" [36]. The sequence shows the end of the myth of "Soviet carelessness" [47]: faced with a nuclear accident, even a great technological power like Japan is nothing more than a house of cards.

\footnotetext{
${ }^{14}$ On the other hand, in the testimony of Masao Yoshida, director of Fukushima Daiichi it highlights the ingenuity of teams in the field during the management of the accident [46].
} 
This negative representation of Naoto Kan should be seen in the context of the criticism he was subject to in Japan. Much of the population believed that the Prime Minister was not up to the situation. His resignation was therefore seen as a milestone in the management of the crisis, "The opposition, but also most of the media, never stopped saying that with the departure of Kan it would at last be possible to begin to resolve the crisis caused by the March 11 earthquake. The psychological and emotional processes at work here seem to have been typical of that of the scapegoat" [48].

The timeframe for the nuclear crisis is not limited to the management of the accident. It seems more relevant to think of Fukushima as a chain reaction, which continues to cause regular crises [49]. Documentaries take particular note of this 'never-ending accident', which is viewed as an unfolding drama. The final scenes of the documentary Welcome to Fukushima [50] evoke a terrifying scenario: the evacuation of more than 50 million Japanese, should a major earthquake occur before the operator can empty the plant's fuel ponds. Such apocalyptic scenarios only prolong the current disaster. Meanwhile, those responsible for remediation and decontamination at the site are subject to extreme working conditions. The exploitation of the human body represents the dark side of post-accident operations, and reminds us of the martyrdom of Soviet operators, convicts of atomic power, "(they) take incredible risks, with just a mask and two gloves, they spend the day in an environment than can exceed three times the amount of radiation tolerated for nuclear workers in France" [51].

The social dimension of the crisis is very apparent. In the documentary Japan: the Silent Nuclear Sector [42] a gymnasium has been transformed into a center for displaced people. A horizontal pan shows the living conditions of 'nuclear refugees', who live in total uncertainty while waiting to be rehoused. Authorities seem to underestimate the extent of the contamination. In Fukushima, the Sacrifice of a Population (Fukushima, une population sacrifiée) [51], a CRIIRAD technician ${ }^{15}$ takes measurements in a primary school in Fukushima City. Off-screen, he reads radiation levels, while students prepare their sports equipment in the background. The depth of field reflects the resignation of the government, which is allowing radioactive pollution to take root in the lives of children.

Documentaries like those made by the Japanese media [52], emphasize that social bonds were destroyed by the accident. Radioactivity isolates and fragments communities, says the narrator of Fukushima, Particles and Mankind [38]. It prevents any return to normality in the contaminated area. The consequences of the disaster disrupt not only lifestyles, but also the relationship between people and things. Decontamination destroys landscapes. In Welcome to Fukushima, a Japanese resident turns this point into an ontological caesura, "If a tree is a 100

\footnotetext{
${ }^{15}$ The Commission for Independent Research and Information on Radioactivity (CRIIRAD) was created in May 1986 after the Chernobyl accident. The role of this independent body is to monitor radioactivity in the environment and materials, evaluate the impact of radioactive releases from nuclear facilities, provide information about radioactivity and its civil and military applications, and protect populations against the risks created by ionizing radiation.
} 
years old, it means that a man planted it two generations earlier. And the tree connects us with that person. [...] But by cutting down trees to clean up, no-one bothers to communicate with them. The tree is nothing more than an object. It's cut down, that's all' [50]. The disaster depopulated territories, ripped society apart and made any dialogue about what is and what is no longer, impossible.

\subsection{The Resilience of Civil Society: A New Representation of the Japanese Population}

The consequences of Fukushima suggest a sacrificial system; a Japanese replica of Chernobyl's 'nuclear Gulag' [53, 54]. ${ }^{16}$ This extreme situation has led to rising levels of criticism. A refugee publicly challenges the CEO of TEPCO, "It might not look like much, but challenging a leader in this way is very rare in Japan" [36]. The disciplined Japanese culture has cracked and the anti-nuclear movement has made significant progress "in a country where demonstrations are extremely rare" [42]. The literature confirms that opposition to nuclear power, which appeared in Japan in the 1970s, has strengthened since the Fukushima accident [56]. But documentaries do not only evoke a change in attitudes and behaviors. They also reflect the surprise of seeing certain archetypes disintegrate. The French media has a particular image of the Japanese population, which is recognized for its spirit of resignation in the face of disaster [57]. The images shot after Fukushima paint a very different picture of Japanese society. A new representation, highlighting the insubordination of a part of the population, appeared on screens.

Documentaries also show the impact of the nuclear accident in France. "Since Fukushima, the debate, which until then French society was only moderately interested in, has taken on a new dimension" [58]. Nuclear Energy: the Human Bomb shows images of anti-nuclear protests, "In France, for the first time, we see that a serious accident is possible" [44]. In an interview, Alain de Halleux talks about the reception of his documentary, NTR Nuclear: Nothing to Report (R.A.S Nucléaire-Rien à signaler) [59]. His film, which received little attention in 2009, was re-broadcast on the French television channel Arte on March 25, 2011 and appears to have found its audience, "Now that a plant has blown up at Fukushima, everybody's asking questions about safety and suddenly, we're finally paying attention to warnings and emergencies" [60]. For Greenpeace, local officials realized that their town, even though it was located $30 \mathrm{~km}$ from a plant, was not immune to accidents, "It's this grass-roots change that we believe will lead to the death of nuclear power in France" [58].

\footnotetext{
${ }^{16}$ Japanese history is often viewed through this prism: the sacrifice of soldiers during the WW2, the sacrifice of Okinawa for the installation of United States' bases, the sacrifice of populations that are allowed to reside in contaminated zones [55].
} 
The question of site safety has restarted the debate on the French 'nucleocracy'. In The World after Fukushima the Japanese nuclear sector is associated with a form of autocratic rule. In Nuclear Power: the French Exception (Nucléaire: exception française) [61] the sector is said to be dangerous, inevitably leading to a militarized and centralized police state. The narrator reminds us of the post-Fukushima context: Germany and Switzerland are planning their exit from nuclear power; Italians declare their opposition to the revival of the sector; and Japan stops the operation of its facilities. France, however, refuses to give up atomic power, "Our governments have made nuclear power a state religion, protected by an all-powerful technocracy" [61]. French dogmatism is presented as an obstacle to common sense: despite the Fukushima accident, the state wants to preserve the industry, which it sees as the guarantor of energy independence and French influence.

Critics of the Japanese and French nuclear sector have united to denounce authoritarian abuses of the system and promote a more separatist society. Documentaries reflect this aspiration, which has emerged from the anti-nuclear movement, by showing the effects of the accident on Japanese civil society. In these representations, the crisis provokes an unprecedented mobilization of the population. New solidarity networks emerged spontaneously. The clearance of contaminated zones has united volunteers from throughout the archipelago, "Me and my parents are from Hiroshima. So we feel particularly affected by radioactivity. So I came here to help" [51]. The victims of military and civilian atomic power appear to belong to a community with a shared destiny.

Such documentaries highlight collective resilience and the re-conquest of social action. The organization 'The Renaissance of Fukushima' brings together farmers, doctors, psychologists, geologists, physicists and retirees. Their mission is to make "the invisible visible" [38]. Members measure soil contamination, exchange data and expertise, and try to find solutions to restart agriculture. The accident interrupted the ancestral practice of working the land. Recovery symbolizes their hope of a renaissance in the contaminated areas.

These images reflect a constellation of positive initiatives and interactions: sharing knowledge and skills, establishing a support system, strengthening links between mankind and nature, and thinking about the meaning of community. The social balance that was destroyed by the disaster must be reconstituted. According to one farmer, "This nuclear accident, it's not only about Fukushima. We all need to take responsibility because we let ourselves be overwhelmed by nuclear power. We must be united and think together" [37]. Local action celebrates the struggle for life, while radioactivity causes necrosis. This neo-activism contrasts with the vertical management of the disaster. We are witnessing the emergence of an alternative society, driven by a deep desire for autonomy, which could regenerate the foundations of democracy. ${ }^{17}$

\footnotetext{
${ }^{17}$ The sociopolitical implications of these initiatives should however be carefully noted, "Since March 11, we have seen the growing importance of local action. But we cannot say if this is a positive development, a move to greater autonomy and better cooperation" [62].
} 


\section{Conclusion}

Representations contribute to social reality by formalizing content that can change ideas and behaviors. They appear during the development of a technical system but also further downstream, especially if the development leads to debate in civil society. The issues that are at stake with respect to nuclear energy have caused deep ideological divisions and sparked renewed controversy, coinciding with the various accidents that have occurred in the sector. Nuclear accidents occupy a special place in the story, in the sense that their effects concern not only the industrial context but also living beings as a whole.

Cultural objects address this immeasurable dimension of the disaster. While they have multiple uses and purposes, what they have in common is that they manifest mourning for technical power and the dramatic consequences of nuclear accidents. Their value for the researcher is that they make it possible to examine the (more or less standardized) formalization of the representation. An analysis of the aestheticization process helps towards a better understanding of how representational elements are realized in a particular cultural system. It is this real-world realization that forms the perimeter of the study of objects.

Although research based on documentaries cannot aim for completeness, it provides food for thought about the impact of Fukushima on representations. The event does not seem to have upset the representational system of nuclear accidents. Films describe a world that could be a duplication of Chernobyl. A radioactive world, which is the demonstration of mankind's technological pride: abandoned territories, sacrificed populations, destinies that have been changed in a Faustian pact with the atom. Behind these images and words, the unwavering shadow of the sarcophagus of the Chernobyl plant looms. The Soviet accident remains the great caesura which changed representations. It created new sensitivities, new ways to show the invisible and say the unsayable. Chernobyl created a mythology, symbolic references, practices, a whole range of signs, almost a language that subsequent documentaries borrowed from to tell the story of Fukushima.

But the representation of Fukushima is not just the transposition of a Japanese Chernobyl. If the central core appears to be intact, new elements appear in the peripheral system. ${ }^{18}$ Fukushima shows that the major technological powers are not safe from a nuclear accident. The idea is not new: the Three Mile Island accident demonstrated this in 1979. But low environmental emissions, skillful government communication, ${ }^{19}$ and the limited means of the anti-nuclear movement have reduced the impact of the accident in France. The scope of Fukushima is very different. The event reactivated the public debate, including elements such as the myth of safety, the nightmare of waste, the exploitation of workers, the nucleocracy, and the desire for social autonomy. While Fukushima has not buried nuclear

\footnotetext{
${ }^{18}$ Caution should be exercised and only broader research will test these hypotheses.

${ }^{19}$ After Three Mile Island, French Prime Minister Raymond Barre announced that "The same scenario that took place in the United States could happen in France" (Le Monde, April 3, 1979).
} 
power in France (or even created a national protest movement), Japan was shaken to its core and is experiencing a social renaissance. The telegenic virtue of the disaster is that it has pedagogical value: it reveals our carelessness and leads us to correct our position [63]. The accident has destabilized technological certainties and anathematized actors in the crisis. It has given renewed meaning to collective action, while the representation of the Japanese population has changed archetypes, showing how civil society can become resilient.

\section{References}

1. Ecole Biblique de Jerusalem (dir.), La Bible de Jérusalem (Editions du Cerf, Paris, 1998), $2117 \mathrm{p}$.

2. P. Bruegel, La tour de Babel, Kunsthistorisches Museum, Vienne, huile sur panneau de bois, $114 \times 155 \mathrm{~cm} .(1563)$

3. P. Robert-Jones, F. Robert-Jones, Bruegel (Flammarion, Paris, 1997), 351 p.

4. F. Walter, Catastrophes, une histoire culturelle XVe-XXIe s (Editions du Seuil, Paris, 2008), $380 \mathrm{p}$.

5. G. Mc CORMACK, Le Japon nucléaire ou l'hubris puni, Le Monde Diplomatique (avril 2011)

6. J. Davallon, Réflexions sur l'efficacité symbolique des productions culturelles. Langage et société, no 24, 37-52 (1983)

7. B. Gaffie, Confrontations des représentations sociales et construction de la réalité. Journal International sur les Représentations Sociales 2(1), 6-19 (2004)

8. S. Moscovici, La psychanalyse, son image et son public (PUF, Paris, 1961, 1976), $506 \mathrm{p}$.

9. Valence, Les représentations sociales (Editions de Boeck, Bruxelles, 2010), 174 p.

10. J.-M. Seca, Les représentations sociales (Armand Colin, Paris, 2010), 217 p.

11. D. Jodelet, Représentation sociale, in Le dictionnaire des sciences humaines, ed. by $\mathrm{S}$. Mesure, P. Savidan (PUF, Paris, 2006), 1277, pp. 1003-1005

12. J.-C. Abric, L'organisation interne des représentations sociales: système central et système périphérique, in Structures et transformations des représentations sociales, ed. by C. Guimelli (Delachaux et Nestlé, Paris, 1994), 277 p.

13. P. Moliner, A. Martos, La fonction génératrice de sens du noyau des représentations sociales: une remise en cause? Papers on Social Representations. Peer Rev. Int. J. (2005)

14. D. Raynaud, Sociologie des controverses scientifiques (PUF, Paris, 2003), 222 p.

15. C. Lemieux, A quoi sert l'analyse des controverses? Mil neuf cent, n 25 (2007), pp. 191-212

16. S. Topçu, La France nucléaire. L'art de gouverner une technologie contestée (Seuil, Paris, 2013), $349 \mathrm{p}$.

17. P. Lascoumes, La productivité sociale des controverses, intervention au séminaire Penser les sciences, les techniques et l'expertise aujourd'hui, EHESS - CNRS (25 janvier 2001)

18. M. Callon, Pour une sociologie des controverses technologiques. Fundamenta Scientiae 2(3/4), 381-399 (1981)

19. S. Boudia, Naissance et rebonds d'une controverses scientifique: les dangers de la radioactivité pendant la guerre froide. Mil Neuf Cent. Revue d'histoire intellectuelle 25, 157-170 (2007)

20. G. Hecht, Le rayonnement de la France, énergie nucléaire et identité nationale après la Seconde Guerre mondiale (Editions de La Découverte, Paris, 2004), 385 p.

21. R. Chartier, P.-A. Fabre, Histoire des représentations, in Le dictionnaire des sciences humaines, ed. by S. Mesure, P. Savidan (PUF, Paris, 2006), 1277, pp. 1005-1007

22. E. Diet, L'objet culturel et ses fonctions médiatrices. Connexions, n 93, pp. 39-59 (2010) 
23. M. Groening, Treehouse of Horror XV. The Simpsons Season 16, 20th Century Fox TV \& Gracie Films, 30 min. (2004)

24. J. Aumont, M. Marie, Dictionnaire théorique et critique du cinéma (Armand Colin, Paris, 2008), $300 \mathrm{p}$.

25. J.-P. Dupuy, Un paradis habité par des meurtriers sans méchanceté et des victimes sans haine: Hiroshima, ernobyl, Fukushima. Ebisu 47, 49-57 (2012)

26. Y. Dupont, (dir.), Dictionnaire des risques (Armand Colin, Paris, 2003), 421 p.

27. D. Le Breton, Sociologie du risque (PUF, Paris, 2012), 127 p.

28. U. Beck, La société du risque. Sur la voie d'une autre modernité (Flammarion, Paris, 1986, 2001), $521 \mathrm{p}$.

29. C. Leon, Silence, on irradie. Editions Thierry Magnier, (2009), 111 p.

30. J.-P. Dupuy, Retour de Tchernobyl, journal d'un homme en colère (Editions du Seuil, Paris, 2006), 179 p.

31. Kurosawa, Rêves - Le Mont Fuji en rouge, Warner Bros, 119 min. (1990)

32. M. Eliade, Images et symboles (Gallimard, Coll. Tel, Paris, 1952), 252 p.

33. S. Sion, The Land of Hope, Rapid Eye Movies \& Third Window Films, 133 min. (2012)

34. E. Lepage, Un printemps à Tchernobyl (Futuropolis, Paris, 2012), 163 p.

35. B. Aflallo, La Gaule sous occupation nucléaire, affiche sur papier recyclé, $29,7 \times 42 \mathrm{~cm}$

36. C. Le Pomellec, Catastrophes nucléaires: histoires secrètes. Tac Presse \& Canal +, 93 min. (2012)

37. K. Watanabe, Le monde après Fukushima, ARTE France \& Kami Productions, $117 \mathrm{~min}$. (2013)

38. G. Rabier, C.-J. Parisot, Fukushima, des particules et des hommes, Kami productions \& France Télévisions, 52 min. (2014)

39. L. Coninck, Fukushima, vers une contamination planétaire, Code 5, 52 min. (2014)

40. J.-J. Delfour, Nucléaire et jouissance technologique. Le Monde (11 avril 2011)

41. Y. Shiokura, Comment un pays irradié est devenu pronucléaire, Courrier Internationale (18 août 2011)

42. S. Lebrun, C. Barreyre, Japon: Nucléaire, la filière du silence, Envoyé Spécial, 30 min. (2011)

43. AFP, Des milliers de manifestants demandent l'arrêt de la centrale de Fessenheim, Le Monde (10 avril 2011)

44. Fayner, Nucléaire: la bombe humaine, France Télévisions \& Chasseurs d'Etoiles, 52 min. (2012)

45. J.-P. Dupuy, Pour un catastrophisme éclairé (Editions du Seuil, Paris, 2002), 214 p.

46. F. Guarnieri, S. Travadel, C. Martin, A. Portelli, A. Afrouss, L'accident de Fukushima Daiichi, le récit du directeur de la centrale, Volume I - L'anéantissement (Presses des Mines, Paris, 2015), $341 \mathrm{p}$.

47. G. Geal, Il faut sortir de la religion de l'atome, Le Monde. (17 mars 2011)

48. T. Guthmann, Gestion de crise et culture politique du Japon contemporain: le Premier ministre Kan Naoto a-t-il réellement failli? Ebisu 47, 81-87 (2012)

49. F. Guarneri, S. Travadel, Engineering thinking in emergency situations: A new nuclear safety concept. Bulletin of Atomic Scientists 70(6), 79-86 (2014)

50. A. De Halleux, Welcome to Fukushima, Simple Production, Crescendo films, L'Indien Productions, 59 min. (2013)

51. D. Zavaglia, Fukushima, une population sacrifiée, LCPAn \& Scientifilms, 52 min. (2012)

52. D. Boilley, Initiatives citoyennes au Japon suite à la catastrophe de Fukushima, 30 p. (février 2012)

53. G. Ackerman, Tchernobyl, retour sur un désastre (Gallimard, Paris, 2006), 162 p.

54. W. Tchertkoff, Le crime de Tchernobyl. Le goulag nucléaire (Actes Sud, Arles, 2006), 717 p.

55. P.-F. Souyri, Les gens de Fukushima ne se sentent pas comme de victimes mais comme des sacrifiées, Le Monde (10 mars 2012)

56. M. Gaulene, Le mouvement antinucléaire japonais depuis Fukushima, CERI - Sciences Po. org, (2012), $11 \mathrm{p}$. 
57. J. Lagane, Catastrophe environnementale au Japon: apport des savoirs profanes et mouvements citoyens. Ebisu 47, 143-150 (2012)

58. J.-C. Deniau, Nucléaire: la grande explication, JEM productions, 75 min. (2012)

59. A. De Halleux, RAS: Nucléaire rien à signaler, Arte \& Crescendo Films, 52 min. (2009)

60. J. Chandoutis, Entretien avec Alain de Halleux, 15 min. (2011)

61. F. Biamonti, Nucléaire: exception française, Morgane et Kami Productions, 70 min. (2013)

62. P. Marmignon, Communautés de quartier et associations: le retour du local après le 11 mars 2011. Ebisu 47, 215-221 (2012)

63. R. Debray, Du bon usage des catastrophes (Gallimard, Paris, 2011), 112 p.

Open Access This chapter is licensed under the terms of the Creative Commons Attribution 4.0 International License (http://creativecommons.org/licenses/by/4.0/), which permits use, sharing, adaptation, distribution and reproduction in any medium or format, as long as you give appropriate credit to the original author(s) and the source, provide a link to the Creative Commons license and indicate if changes were made.

The images or other third party material in this chapter are included in the chapter's Creative Commons license, unless indicated otherwise in a credit line to the material. If material is not included in the chapter's Creative Commons license and your intended use is not permitted by statutory regulation or exceeds the permitted use, you will need to obtain permission directly from the copyright holder.

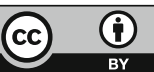

